\title{
Computational Study of Geometry, IR Spectrum and Molecular Properties of Acetanilide
}

\author{
Mohammad Firoz Khan ${ }^{1}$, Rahatullah Razan ${ }^{1}$, Ridwan Bin Rashid ${ }^{2}$, Faiza Tahia ${ }^{3}$ \\ and Mohammad A. Rashid ${ }^{3}$ \\ ${ }^{1}$ Department of Pharmacy, State University of Bangladesh, Dhaka-1205, Bangladesh \\ ${ }^{2}$ Department of Microbiology, University of Dhaka, Dhaka-1000, Bangladesh \\ ${ }^{3}$ Department of Pharmaceutical Chemistry, Faculty of Pharmacy, University of Dhaka, Dhaka-1000, Bangladesh
}

Received: June 01, 2016; Accepted: June 29, 2016; Published (Web): July 31, 2016

\begin{abstract}
In this paper an effort has made to conduct and repot the computational study of geometry, IR spectrum and different molecular properties like Molecular Electrostatic Potential (MESP), Mulliken Charge Distribution, Global Reactivity Descriptors such as chemical hardness, softness, chemical potential, electronegativity, and electrophilicity index of acetanilide. All calculations were performed on Hartee-Fock (HF), Becke and 3-parameter, Lee-Yang-Parr (B3LYP) with 6-31G(d) and $6-31+\mathrm{G}(\mathrm{d}, \mathrm{p})$ basis sets. The calculated geometries (bond length, bond angle and dihedral angle) were in a good agreement with the experimental data for both level of theories and basis sets. In case of IR frequencies the scaled calculated frequencies agreed reasonably well with the experimental results.
\end{abstract}

Key words: Acetanilide, vibrational frequency, molecular electrostatic potential, chemical potential, electronegativity, electrophilicity index

\section{Introduction}

Acetanilide (Figure 1), also known as $\mathrm{N}$ phenylacetamide, acetanil, or acetanilide is a white to gray solid with molecular formula $\mathrm{CH}_{3} \mathrm{CONHC}_{6} \mathrm{H}_{5}$. It is an odorless (Lewis et al., 1993) colorless, glossy, crystalline material (Gerhartz, 1985) having molecular weight, boiling and melting point $135.16,304^{\circ}$ and $114.3^{\circ} \mathrm{C}$, respectively. Acetanilide was the first aniline derivative found to possess analgesic as well as antipyretic properties and was quickly introduced into medical practice (Weast, 1981; Gnanasambandan et al., 2014). Later, it was established that in the human body it is mostly metabolized to paracetamol, this compound being responsible for the analgesic and antipyretic properties of acetanilide (Bertolini et al., 2006; Gnanasambandan et al., 2014). In addition, it was discovered that it has unacceptable toxic effects, so that acetanilide is no longer used as a drug. The word "acetanilide" appears in the title of more than 200 scientific articles in the last 35 years, mainly related to the following topics: (i) peculiar spectroscopy of crystalline acetanilide and quantum vibrational polarons
(Hamm and Tsironis, 2007; Gnanasambandan et al., 2014) (ii) herbicide properties of its derivatives (Pereira et al., 2010; Gnanasambandan et al., 2014) (iii) thermodynamic properties of its mixtures (Baena, 2004; Gnanasambandan et al., 2014).

Acetanilide is used as an inhibitor of hydrogen peroxide decomposition and to stabilize cellulose ester varnishes. It is also used in the intermediation of rubber accelerator synthesis, dyes and dye intermediate synthesis, and camphor synthesis. Acetanilide is used for the production of 4-acetamidobenzenesulfonyl chloride, a key intermediate for the manufacture of the sulfa drugs. It is also a precursor in the synthesis of penicillin and other pharmaceuticals. In the 19th century acetanilide was one of a large number of compounds used as experimental photographic developers.

Several investigations on acetanilide were conducted previously. The X-ray crystal structure and IR spectra of acetanilide was reported earlier (Brown and Corbridge, 1954; Itoh and Shimanouchi, 1969; Wasserman et al., 1985). Cheshmedzhieva et al. (2004)

Correspondence to: Mohammad A. Rashid; E-mail: rashidma@du.ac.bd 
investigated the alkaline hydrolysis of acetanilide computationally. Decoret and Tinland (1972) studied the conformation of acetanilide theoretically. Moreover, the theoretical study of electronic structure and spectrum of acetanilide were also reported by Decoret and Tinland (1971).

To the best of our knowledge, the theoretical calculation and effects of various level of theories and basis sets on molecular geometry (bond length, bond angle and dihedral angle), IR spectra and different molecular properties such as Molecular electrostatic potential (MESP), Mulliken charge distribution, Global reactivity descriptors (chemical hardness, softness, chemical potential, electronegativity, electrophilicity index) of acetanilide have not been reported previously.

\section{Computational methods}

All calculations were carried out with the Gaussian09 software package (Frisch et al., 2009). The geometries were fully optimized and the frequencies were calculated in the gas phase at the Hartee-Fock (HF) and Becke, 3-parameter, Lee-Yang-Parr (B3LYP) level of theories using $6-31 \mathrm{G}(\mathrm{d})$ and $6-31+\mathrm{G}(\mathrm{d}, \mathrm{p})$ basis

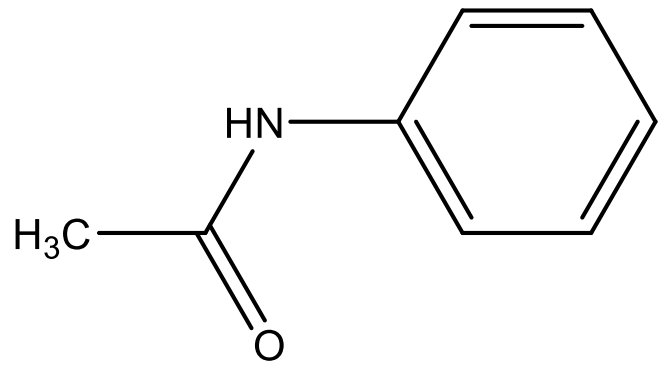

sets. Mulliken charge distribution was also calculated with the same level of theories and basis sets. In addition, MESP and global reactivity descriptors such as hardness, chemical potential, softness, electronegativity and electrophilicity index have also been calculated in the gas phase. Frequencies were scaled using the scale factors summarized in (Table 1) for all level of theories and basis sets employed (Merrick et al., 2007). The absence of negative frequencies confirmed that the stationary points correspond to minima on the potential energy surface. In total there are 51 vibrations and the assignments of the calculated wave numbers were aided by the animation option of the program GaussView (Dennington et al., 2009).

Table 1. Scaling factor suitable for vibrational frequencies (Merrick, et al., 2007).

\begin{tabular}{lcc}
\hline Basis sets & B3LYP & HF \\
\hline 6-31G(d) & 0.9613 & 0.8953 \\
6-31+G(d,p) & 0.9648 & 0.9007 \\
\hline
\end{tabular}

Figure 1. Structure of acetanilide.

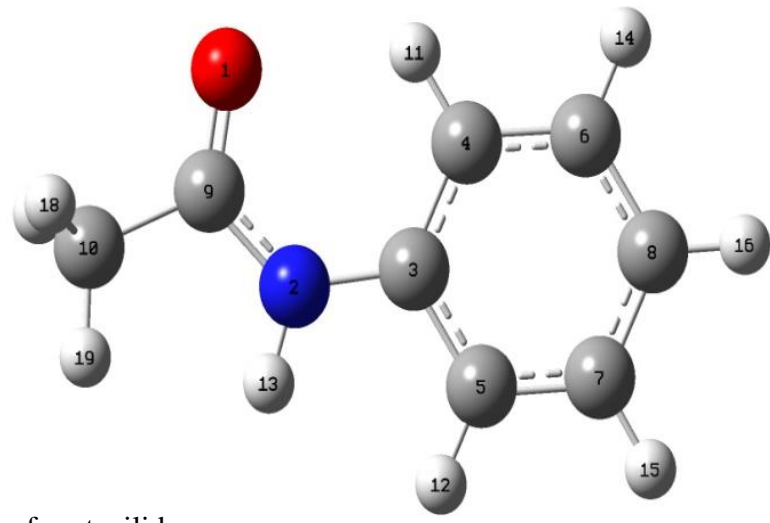

\section{Results and Discussion}

Equilibrium geometries: The optimized geometrical parameters such as bond lengths, bond angles and dihedral angles of acetanilide obtained by the HF and B3LYP methods with 6-31G(d) and 6$31+\mathrm{G}(\mathrm{d}, \mathrm{p})$ as basis sets are listed in tables 2, 3 and 4 . The computed bond length and bond angles were compared with X-ray diffraction data of similar compound. From tables 2 and 3, it can be seen that there are some deviations in the computed geometrical parameters which are expressed as Mean Absolute Deviation (MAD). From table 4 it can be seen that all the computed dihedral angle are in close to each other irrespective of the level of theories and basis sets used; but larger deviations are observed in the dihedral angles 
of $\mathrm{O}(1)-\mathrm{C}(9)-\mathrm{C}(10)-\mathrm{H}(17), \mathrm{O}(1)-\mathrm{C}(9)-\mathrm{C}(10)-\mathrm{H}(18)$ and $\mathrm{O}(1)-\mathrm{C}(9)-\mathrm{C}(10)-\mathrm{H}(19)$.

Vibrational frequencies in gas phase: All calculated frequency values presented in this paper are obtained within the harmonic approximation. A comparison of calculated and experimental vibrational frequencies for acetanilide is presented in table 5 which shows that even after scaling, large frequency shifts (above $50 \mathrm{~cm}^{-1}$ ) are observed for $v 13, v 14, v 15, v 30$, v31, v40, v42, v48, v48, v50 and v51. The largest frequency shift, $215 \mathrm{~cm}^{-1}$, corresponds to the $\mathrm{N}$ Hstretching. The calculated vibrational frequencies for stretching modes of $\mathrm{C}=\mathrm{O}$ and $\mathrm{N}-\mathrm{H}$ are observed in the region 1696-1774 and 3468-3509 $\mathrm{cm}^{-1}$, respectively. These values agree reasonably well with the experimental results.

Table 2. Theoretical (gas phase) and experimental (X-ray diffraction) bond distances (̊̊) of acetanilide.

\begin{tabular}{|c|c|c|c|c|c|}
\hline \multirow[b]{2}{*}{ Assignment } & \multicolumn{2}{|c|}{$6-31 G(d)$} & \multicolumn{2}{|c|}{$6-31+G(d, p)$} & \multirow{2}{*}{$\begin{array}{c}\text { Experimental } \\
\text { (Brown and Corbridge, } \\
\text { 1954) }\end{array}$} \\
\hline & B3LYP & $\mathrm{HF}$ & B3LYP & $\mathrm{HF}$ & \\
\hline$C(3)-C(4)$ & 1.404 & 1.391 & 1.404 & 1.391 & 1.391 \\
\hline$C(3)-C(5)$ & 1.404 & 1.392 & 1.406 & 1.394 & 1.397 \\
\hline$C(4)-C(6)$ & 1.395 & 1.386 & 1.397 & 1.389 & 1.384 \\
\hline$C(5)-C(7)$ & 1.392 & 1.382 & 1.393 & 1.383 & 1.379 \\
\hline$C(6)-C(8)$ & 1.395 & 1.384 & 1.396 & 1.385 & 1.376 \\
\hline$C(7)-C(8)$ & 1.396 & 1.385 & 1.398 & 1.387 & 1.391 \\
\hline $\mathrm{C}(3)-\mathrm{N}(2)$ & 1.412 & 1.409 & 1.414 & 1.410 & 1.413 \\
\hline $\mathrm{C}(9)-\mathrm{N}(2)$ & 1.380 & 1.365 & 1.378 & 1.363 & 1.354 \\
\hline $\mathrm{C}(9)=\mathrm{O}(1)$ & 1.222 & 1.197 & 1.226 & 1.200 & 1.219 \\
\hline $\mathrm{C}(9)-\mathrm{C}(10)$ & 1.525 & 1.516 & 1.521 & 1.514 & 1.495 \\
\hline $\mathrm{C}(4)-\mathrm{H}(11)$ & 1.081 & 1.068 & 1.081 & 1.069 & - \\
\hline $\mathrm{C}(5)-\mathrm{H}(12)$ & 1.089 & 1.077 & 1.088 & 1.077 & - \\
\hline $\mathrm{C}(6)-\mathrm{H}(14)$ & 1.087 & 1.076 & 1.086 & 1.076 & - \\
\hline $\mathrm{C}(7)-\mathrm{H}(15)$ & 1.087 & 1.075 & 1.086 & 1.076 & - \\
\hline $\mathrm{C}(8)-\mathrm{H}(16)$ & 1.086 & 1.075 & 1.086 & 1.075 & - \\
\hline $\mathrm{N}(2)-\mathrm{H}(13)$ & 1.011 & 0.995 & 1.010 & 0.993 & - \\
\hline $\mathrm{C}(10)-\mathrm{H}(17)$ & 1.097 & 1.086 & 1.094 & 1.086 & - \\
\hline $\mathrm{C}(10)-\mathrm{H}(18)$ & 1.090 & 1.079 & 1.094 & 1.081 & - \\
\hline $\mathrm{C}(10)-\mathrm{H}(19)$ & 1.097 & 1.085 & 1.094 & 1.084 & - \\
\hline MAD & 0.013 & 0.008 & 0.013 & 0.007 & \\
\hline
\end{tabular}

Molecular electrostatic potential (MESP): In the graphic of total electron density surface mapped with the electrostatic potential, the sign of the electrostatic potential in a surface region is determined by the predominance of negative or positive charges contribution. Accordingly, it is possible to identify regions more susceptible to electrophilic or nucleophilic molecules, so the molecular electrostatic potential map is commonly used as reactivity map (Govindarajan et al., 2012). To predict regions more susceptible to electrophiles or nucleophiles, MESP was calculated at the B3LYP/6-31+G (d,p) and is shown in figure 2. The importance of total electron density surface mapped with the electrostatic potential lies in the fact that it simultaneously displays molecular size, shape, as well as positive or negative electrostatic potential regions in terms of color grading and is very useful in research of 
molecular structure with its physiochemical property relationship (Munoz-Caro et al., 2000).

The different values of the electrostatic potential are represented by different colors. It is accepted that the negative (red) and the positive (blue) potential regions in the mapped MESP represent regions susceptible to approach electrophiles and nucleophiles, respectively.

Table 3. Selected theoretical (gas phase) and experimental (X-ray diffraction) bond angles ( $(\AA)$ of acetanilide.

\begin{tabular}{|c|c|c|c|c|c|}
\hline \multirow{2}{*}{ Assignment } & \multicolumn{2}{|c|}{$6-31 G(d)$} & \multicolumn{2}{|c|}{$6-31+\mathrm{G}(\mathrm{d}, \mathrm{p})$} & \multirow{2}{*}{$\begin{array}{c}\text { Experimental } \\
\text { (Brown and Corbridge, } \\
1954)\end{array}$} \\
\hline & B3LYP & $\mathrm{HF}$ & B3LYP & $\mathrm{HF}$ & \\
\hline$C(3)-C(5)-C(7)$ & 120.5 & 120.6 & 120.5 & 120.6 & 120.2 \\
\hline$C(5)-C(7)-C(8)$ & 120.3 & 120.3 & 120.2 & 120.3 & 120.4 \\
\hline $\mathrm{C}(7)-\mathrm{C}(8)-\mathrm{C}(6)$ & 119.1 & 118.9 & 119.1 & 118.9 & 119.0 \\
\hline$C(8)-C(6)-C(4)$ & 121.4 & 121.5 & 121.4 & 121.5 & 121.7 \\
\hline$C(6)-C(4)-C(3)$ & 119.3 & 119.3 & 119.3 & 119.3 & 119.1 \\
\hline $\mathrm{C}(4)-\mathrm{C}(3)-\mathrm{C}(5)$ & 119.4 & 119.3 & 119.5 & 119.4 & 119.6 \\
\hline $\mathrm{C}(5)-\mathrm{C}(3)-\mathrm{N}(2)$ & 117.3 & 116.9 & 117.1 & 116.8 & 116.6 \\
\hline $\mathrm{C}(4)-\mathrm{C}(3)-\mathrm{N}(2)$ & 123.3 & 123.8 & 123.4 & 123.8 & 123.8 \\
\hline $\mathrm{C}(3)-\mathrm{N}(2)-\mathrm{C}(9)$ & 129.3 & 129.4 & 129.4 & 129.2 & 127.6 \\
\hline $\mathrm{C}(10)-\mathrm{C}(9)-\mathrm{N}(2)$ & 113.4 & 113.5 & 114.8 & 114.5 & 115.3 \\
\hline $\mathrm{N}(2)-\mathrm{C}(9)-\mathrm{O}(1)$ & 124.1 & 124.4 & 123.9 & 124.2 & 123.1 \\
\hline $\mathrm{C}(10)-\mathrm{C}(9)-\mathrm{O}(1)$ & 122.4 & 122.1 & 121.4 & 121.3 & 121.6 \\
\hline MAD & 0.7 & 0.6 & 0.5 & 0.4 & \\
\hline
\end{tabular}

Table 4. Theoretical (gas phase) dihedral angles $(\AA)$ of acetanilide.

\begin{tabular}{|c|c|c|c|c|c|c|c|c|c|}
\hline \multirow{2}{*}{ Assignment } & \multicolumn{2}{|c|}{$6-31 G(d)$} & \multicolumn{2}{|c|}{$6-31+G(d, p)$} & \multirow{2}{*}{ Assignment } & \multicolumn{2}{|c|}{$6-31 G(d)$} & \multicolumn{2}{|c|}{$6-31+G(d, p)$} \\
\hline & B3LYP & $\mathrm{HF}$ & B3LYP & $\mathrm{HF}$ & & B3LYP & $\mathrm{HF}$ & B3LYP & $\mathrm{HF}$ \\
\hline $\mathrm{H}(12)-\mathrm{C}(5)-\mathrm{C}(7)-\mathrm{H}(15)$ & 0.0 & 0.0 & 0.0 & 0.0 & $\mathrm{H}(11)-\mathrm{C}(4)-\mathrm{C}(3)-\mathrm{N}(2)$ & 0.0 & 0.0 & 0.0 & -0.1 \\
\hline $\mathrm{H}(12)-\mathrm{C}(5)-\mathrm{C}(7)-\mathrm{C}(8)$ & -180.0 & 180.0 & 180.0 & 180.0 & $\mathrm{H}(11)-\mathrm{C}(4)-\mathrm{C}(3)-\mathrm{C}(5)$ & -180.0 & -180.0 & 180.0 & -180.0 \\
\hline $\mathrm{C}(5)-\mathrm{C}(7)-\mathrm{C}(8)-\mathrm{H}(16)$ & 180.0 & -180.0 & -180.0 & -180.0 & $\mathrm{C}(4)-\mathrm{C}(3)-\mathrm{C}(5)-\mathrm{C}(7)$ & 0.0 & 0.0 & 0.0 & 0.0 \\
\hline $\mathrm{C}(5)-\mathrm{C}(7)-\mathrm{C}(8)-\mathrm{C}(6)$ & 0.0 & 0.0 & 0.0 & 0.0 & $\mathrm{C}(3)-\mathrm{C}(5)-\mathrm{C}(7)-\mathrm{C}(8)$ & 0.0 & 0.0 & 0.0 & 0.0 \\
\hline $\mathrm{H}(15)-\mathrm{C}(7)-\mathrm{C}(8)-\mathrm{H}(16)$ & 0.0 & 0.0 & 0.0 & 0.0 & $\mathrm{C}(4)-\mathrm{C}(3)-\mathrm{C}(5)-\mathrm{H}(12)$ & 180.0 & 180.0 & -180.0 & -180.0 \\
\hline $\mathrm{H}(15)-\mathrm{C}(7)-\mathrm{C}(8)-\mathrm{C}(6)$ & 180.0 & -180.0 & 180.0 & -180.0 & $\mathrm{H}(12)-\mathrm{C}(5)-\mathrm{C}(3)-\mathrm{N}(2)$ & 0.0 & 0.0 & 0.0 & 0.1 \\
\hline $\mathrm{C}(7)-\mathrm{C}(8)-\mathrm{C}(6)-\mathrm{H}(14)$ & 180.0 & 180.0 & 180.0 & 180.0 & $\mathrm{C}(5)-\mathrm{C}(3)-\mathrm{N}(2)-\mathrm{H}(13)$ & -0.1 & 0.0 & 0.0 & 0.0 \\
\hline $\mathrm{C}(7)-\mathrm{C}(8)-\mathrm{C}(6)-\mathrm{C}(4)$ & 0.0 & 0.0 & 0.0 & 0.0 & $\mathrm{C}(4)-\mathrm{C}(3)-\mathrm{N}(2)-\mathrm{H}(13)$ & 179.9 & 180.0 & -180.0 & -179.9 \\
\hline $\mathrm{H}(16)-\mathrm{C}(8)-\mathrm{C}(6)-\mathrm{H}(14)$ & 0.0 & 0.0 & 0.0 & 0.0 & $\mathrm{C}(3)-\mathrm{N}(2)-\mathrm{C}(9)-\mathrm{O}(1)$ & -0.1 & -0.1 & 0.0 & -1.4 \\
\hline $\mathrm{H}(16)-\mathrm{C}(8)-\mathrm{C}(6)-\mathrm{C}(4)$ & -180.0 & -180.0 & -180.0 & -180.0 & $\mathrm{C}(3)-\mathrm{N}(2)-\mathrm{C}(9)-\mathrm{C}(10)$ & 179.6 & 179.7 & -180.0 & 177.2 \\
\hline $\mathrm{C}(8)-\mathrm{C}(6)-\mathrm{C}(4)-\mathrm{H}(11)$ & 180.0 & 180.0 & 180.0 & 180.0 & $\mathrm{H}(13)-\mathrm{N}(2)-\mathrm{C}(9)-\mathrm{O}(1)$ & 180.0 & -180.0 & 180.0 & 180.0 \\
\hline $\mathrm{C}(8)-\mathrm{C}(6)-\mathrm{C}(4)-\mathrm{C}(3)$ & 0.0 & 0.0 & 0.0 & 0.0 & $\mathrm{H}(13)-\mathrm{N}(2)-\mathrm{C}(9)-\mathrm{C}(10)$ & -0.3 & -0.1 & 0.0 & -1.4 \\
\hline $\mathrm{H}(14)-\mathrm{C}(6)-\mathrm{C}(4)-\mathrm{H}(11)$ & 0.0 & 0.0 & 0.0 & 0.0 & $\mathrm{O}(1)-\mathrm{C}(9)-\mathrm{C}(10)-\mathrm{H}(17)$ & 61.3 & 118.0 & 58.1 & 85.0 \\
\hline $\mathrm{H}(14)-\mathrm{C}(6)-\mathrm{C}(4)-\mathrm{C}(3)$ & -180.0 & 180.0 & 180.0 & -180.0 & $\mathrm{O}(1)-\mathrm{C}(9)-\mathrm{C}(10)-\mathrm{H}(18)$ & -55.0 & -1.9 & -58.3 & -32.4 \\
\hline $\mathrm{C}(6)-\mathrm{C}(4)-\mathrm{C}(3)-\mathrm{N}(2)$ & 180.0 & 180.0 & -180.0 & 179.9 & $\mathrm{O}(1)-\mathrm{C}(9)-\mathrm{C}(10)-\mathrm{H}(19)$ & -176.9 & -122.1 & 179.9 & -154.3 \\
\hline
\end{tabular}


Table 5. Selected theoretical (gas phase) and experimental vibration frequencies $\left(\mathrm{cm}^{-1}\right)$ of acetanilide after scaling.

\begin{tabular}{cccccccccccc}
\hline Mode & \multicolumn{2}{c}{$6-31 \mathrm{G}(\mathrm{d})$} & \multicolumn{2}{c}{$6-31+\mathrm{G}(\mathrm{d}, \mathrm{p})$} & $\begin{array}{c}\text { Experimental } \\
\text { (Internet 1) }\end{array}$ & Mode & \multicolumn{2}{c}{$6-31 \mathrm{G}(\mathrm{d})$} & \multicolumn{2}{c}{$6-31+\mathrm{G}(\mathrm{d}, \mathrm{p})$} & Experimental \\
& B3LYP & HF & B3LYP & HF & B & HF & B3LYP & HF & (Internet 1) \\
$v 9$ & 495 & 496 & 498 & 500 & 506 & $v 34$ & 1372 & 1390 & 1356 & 1385 & 1393 \\
$v 10$ & 514 & 513 & 516 & 514 & 511 & $v 35$ & 1427 & 1436 & 1418 & 1430 & 1436 \\
$v 11$ & 522 & 523 & 531 & 523 & 534 & $v 36$ & 1441 & 1449 & 1423 & 1440 & 1489 \\
$v 12$ & 604 & 597 & 607 & 603 & 607 & $v 37$ & 1460 & 1458 & 1442 & 1453 & 1501 \\
$v 13$ & 608 & 607 & 608 & 608 & 694 & $v 38$ & 1401 & 1498 & 1478 & 1495 & 1538 \\
$v 14$ & 646 & 651 & 647 & 653 & 754 & $v 39$ & 1517 & 1545 & 1507 & 1543 & 1557 \\
$v 15$ & 680 & 691 & 680 & 691 & 761 & $v 40$ & 1590 & 1613 & 1584 & 1611 & 1699 \\
$v 16$ & 742 & 763 & 742 & 763 & 768 & $v 41$ & 1600 & 1619 & 1593 & 1617 & 1620 \\
$v 20$ & 926 & 933 & 927 & 935 & 908 & $v 42$ & 1722 & 1774 & 1696 & 1752 & 1665 \\
$v 21$ & 929 & 973 & 944 & 975 & 962 & $v 44$ & 3016 & 2930 & 3023 & 2941 & 3022 \\
$v 22$ & 961 & 982 & 970 & 993 & 999 & $v 45$ & 3022 & 2990 & 3025 & 2979 & 3046 \\
$v 25$ & 1021 & 1019 & 1015 & 1018 & 1014 & $v 46$ & 3043 & 2991 & 3053 & 2997 & 3059 \\
$v 26$ & 1024 & 1044 & 1018 & 1043 & 1042 & $v 47$ & 3064 & 3009 & 3073 & 3015 & 3083 \\
$v 29$ & 1168 & 1170 & 1164 & 1169 & 1180 & $v 48$ & 3073 & 3019 & 3082 & 3025 & 3137 \\
$v 30$ & 1203 & 1185 & 1197 & 1188 & 1266 & $v 49$ & 3087 & 3034 & 3096 & 3039 & 3196 \\
$v 31$ & 1235 & 1213 & 1228 & 1211 & 1307 & $v 50$ & 3149 & 3102 & 3148 & 3102 & 3261 \\
$v 32$ & 1302 & 1263 & 1300 & 1264 & 1324 & $v 51$ & 3475 & 3468 & 3504 & 3509 & 3294 \\
$v 33$ & 1317 & 1324 & 1317 & 1324 & 1369 & & & & & & \\
\hline
\end{tabular}

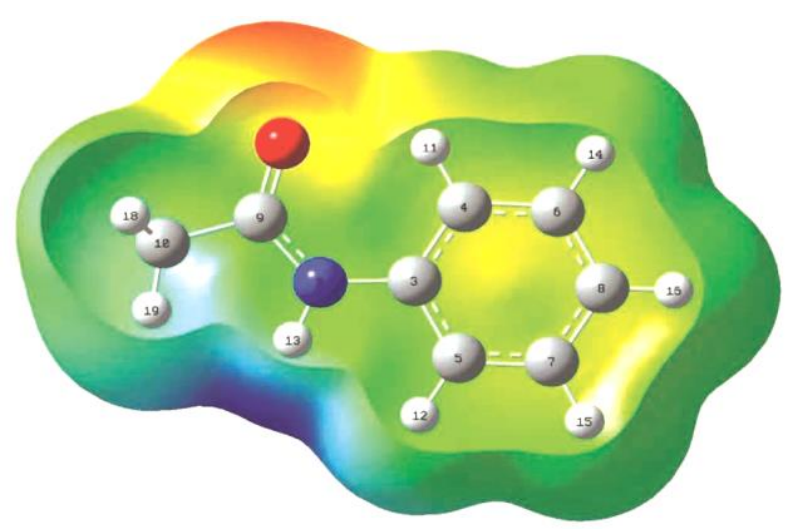

Figure 2. 3D plots of molecular electrostatic potential of acetanilide.

In fact, the mapped MESP over a single surface does not suffice to point out which ligand's regions are more prone to incoming electrophilic species. To really find out these regions the MESP's contour map of the ligand is used. Spatial regions denser in MESP's contour lines present stronger electrostatic fields than the region with less contour line. Also, electrostatic

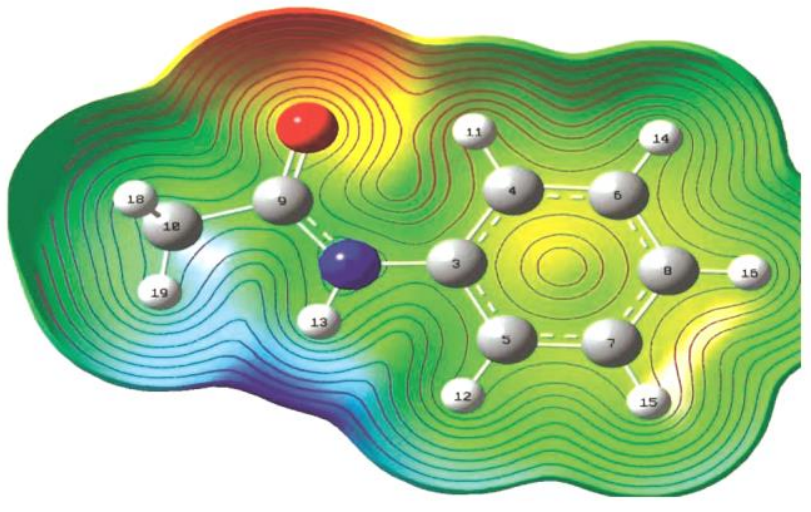

Figure 3. Electrostatic potential contour of acetanilide.

field planar projection points orthogonally towards decreasing MESP contours. Therefore, in general, the red regions depictured in the total electron density surface mapped with the MESP indicate the occurrence of inward electrostatic fields, which favor the approach of electrophilic species and repel nucleophilic ones. It can be seen that the most possible sites for nucleophilic 
attack is C9, which is in accordance with the established data (Cheshmedzhieva et al., 2004) and H13. A negative region in the studied molecule is found around the $\mathrm{O} 1$ atoms indicating a possible site for electrophilic attack (Morrison, 2005).

According to these calculated results, the MEP map shows that the negative potential sites are on electronegative atoms as well as the positive potential sites are around the hydrogen and carbon atoms. The contour map (Figure 3) provides a simple way to predict how different geometries could interact with each other.

Mulliken charge distribution: The Mulliken populations show one of the simplest pictures of charge distribution. The Mulliken charges provide net atomic populations in the molecule while electrostatic potentials yield the electric field out of the molecule produced by the internal charge distribution. Thus, in the reactivity studies, Mulliken populations and MESP are complementary tools, and correlation between the schemes is expected (Santamaria et al., 1998). However, Mulliken population analysis require very careful attention because large changes of calculated atomic charges were observed due to the small changes in basis sets which may lead to the overestimation of covalent character of a bond. In general, the absolute magnitude of the atomic charges has little physical meaning; on the other hand, their relative values can offer valuable information. The Mulliken charge distribution of the title molecule was calculated on HF and B3LYP level with 6-31G(d) and 6-31+G(d,p) basis sets.

The charge distribution of the compound (Table 6) shows that carbon atom $\mathrm{C} 9$ attached with oxygen atoms have positive charges and it is the highest Mulliken charge when compared to other $\mathrm{C}$ atoms. All the hydrogen atoms have positive Mulliken charges and the hydrogen atom (H13) attached to Nitrogen (N2) has the highest positive charge. The $\mathrm{O} 1$ bears negative Mulliken charge and it is the highest when B3LYP/6$31 \mathrm{G}(\mathrm{d}, \mathrm{p})$ method is applied. Moreover, the Mulliken charge distribution and the MESP information are in concordant.

Table 6. Mulliken atomic charges of acetanilide.

\begin{tabular}{|c|c|c|c|c|c|c|c|c|c|}
\hline \multirow{2}{*}{ Atom } & \multicolumn{2}{|c|}{$6-31 \mathrm{G}(\mathrm{d})$} & \multicolumn{2}{|c|}{$6-31+G(d, p)$} & \multirow{2}{*}{ Atom } & \multicolumn{2}{|c|}{$6-31 \mathrm{G}(\mathrm{d})$} & \multicolumn{2}{|c|}{$6-31+\mathrm{G}(\mathrm{d}, \mathrm{p})$} \\
\hline & B3LYP & $\mathrm{HF}$ & B3LYP & $\mathrm{HF}$ & & B3LYP & $\mathrm{HF}$ & B3LYP & $\mathrm{HF}$ \\
\hline $\mathrm{O}(1)$ & -0.492 & -0.588 & -0.508 & -0.584 & $\mathrm{H}(11)$ & 0.187 & 0.275 & 0.170 & 0.220 \\
\hline $\mathrm{N}(2)$ & -0.709 & -0.900 & -0.356 & -0.512 & $\mathrm{H}(12)$ & 0.118 & 0.191 & 0.103 & 0.146 \\
\hline$C(3)$ & 0.352 & 0.363 & -0.293 & -0.473 & $\mathrm{H}(13)$ & 0.328 & 0.392 & 0.285 & 0.326 \\
\hline $\mathrm{C}(4)$ & -0.162 & -0.240 & 0.580 & 0.410 & $\mathrm{H}(14)$ & 0.134 & 0.205 & 0.129 & 0.171 \\
\hline$C(5)$ & -0.196 & -0.265 & -0.404 & -0.049 & $\mathrm{H}(15)$ & 0.130 & 0.202 & 0.125 & 0.169 \\
\hline $\mathrm{C}(6)$ & -0.144 & -0.191 & -0.286 & -0.249 & $\mathrm{H}(16)$ & 0.128 & 0.200 & 0.123 & 0.168 \\
\hline$C(7)$ & -0.133 & -0.188 & -0.183 & -0.227 & $\mathrm{H}(17)$ & 0.190 & 0.191 & 0.188 & 0.171 \\
\hline $\mathrm{C}(8)$ & -0.127 & -0.216 & -0.057 & -0.152 & $\mathrm{H}(18)$ & 0.191 & 0.222 & 0.188 & 0.179 \\
\hline $\mathrm{C}(9)$ & 0.603 & 0.757 & 0.728 & 0.662 & $\mathrm{H}(19)$ & 0.143 & 0.188 & 0.133 & 0.126 \\
\hline $\mathrm{C}(10)$ & -0.541 & -0.596 & -0.665 & -0.502 & & & & & \\
\hline
\end{tabular}

Global reactivity descriptors: The energy gap between HOMO and LUMO is a critical parameter to determine molecular electrical transport properties. By using HOMO and LUMO energy values for a molecule, the global chemical reactivity descriptors of molecules such as hardness, chemical potential, softness, electronegativity and electrophilicity index as well as local reactivity have been defined (Parr et al.,1978; Parr et al.,1983; Parr et al., 1991; Parr et al., 1999; Chattaraj et al., 2003;). Pauling introduced the concept of electronegativity as the power of an atom in a molecule to attract electrons to it. Using Koopman's theorem for closed-shell molecules the hardness $(\eta)$, chemical 
potential $(\mu)$ and electronegativity (x) and softness (S) are defined follows.

$$
\begin{gathered}
\eta=\frac{I-A}{2} \\
\mu=-\frac{I+A}{2} \\
\chi=\frac{I+A}{2} \\
S=\frac{1}{\eta}
\end{gathered}
$$

Where I and A are the ionization potential and electron affinity of the molecules respectively. The ionization energy and electron affinity (Figure 4) can be expressed through HOMO and LUMO orbital energies as $\mathrm{I}=-\mathrm{E}_{\mathrm{HOMO}}$ and $\mathrm{A}=-\mathrm{E}_{\mathrm{LUMO}}$.

Considering the chemical hardness, (Table 7) large HOMO-LUMO gap means a hard molecule and small HOMO-LUMO gap means a soft molecule. One can also relate the stability of the molecule to hardness, which means that the molecule with least HOMOLUMO gap is more reactive (Gnanasambandan et al., 2014). Recently, Parr et al. (1999) have defined a new descriptor to quantify the global electrophilic power of the molecule as electrophilicity index $(\omega)$, which defines a quantitative classification of the global electrophilic nature of a molecule Parr et al. (1999) have defined electrophilicity index $(\omega)$ as follows:

$\omega=\frac{\mu^{2}}{2 \eta}$

Using the above equations, the chemical potential, hardness and electrophilicity index have been calculated for Acetanilide and their values are shown in Table 8 . The usefulness of this new reactivity quantity has been recently demonstrated in understanding the toxicity of various pollutants in terms of their reactivity and site selectivity (Parthasarathi et al., 2003; Parthasarathi et al., 2004a; Parthasarathi et al., 2004b).

\begin{tabular}{|c|c|c|c|c|}
\hline \multirow{2}{*}{ Molecular properties } & \multicolumn{2}{|c|}{$6-31 G(d)$} & \multicolumn{2}{|c|}{$6-31+\mathrm{G}(\mathrm{d}, \mathrm{p})$} \\
\hline & $\mathrm{HF}$ & B3LYP & $\mathrm{HF}$ & B3LYP \\
\hline Еномо $(\mathrm{eV})$ & -8.2557 & -5.9532 & -8.4639 & -6.3088 \\
\hline$E_{\text {LUMO }}(\mathrm{eV})$ & 3.9110 & -0.2800 & 1.6003 & -0.7366 \\
\hline Eномо-Luмо gap (eV) & -12.1667 & -5.6732 & -10.0641 & -5.5722 \\
\hline Еномо-1 $\left._{\text {неV }}\right)$ & -9.1096 & -6.7749 & -9.2805 & -7.1006 \\
\hline ELUMO+1 $(\mathrm{eV})$ & 3.9929 & 0.0335 & 2.0748 & -0.4952 \\
\hline Еномо-1 - LuMO+1 gap (eV) & -13.1025 & -6.8084 & -11.3553 & -6.6054 \\
\hline
\end{tabular}

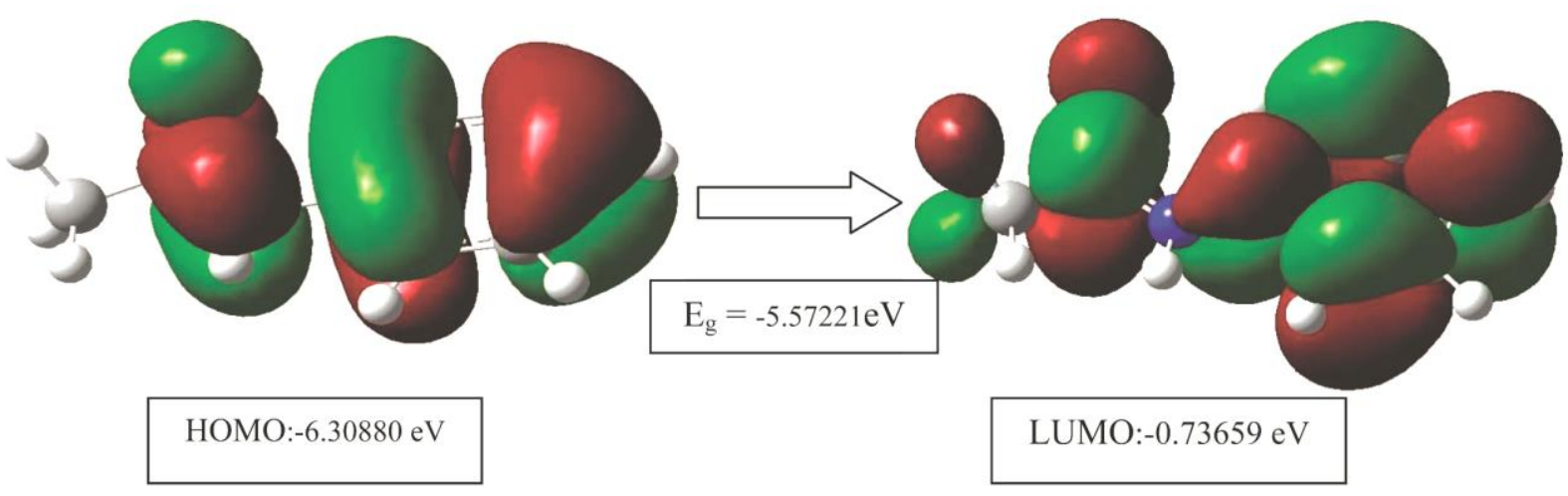

Figure 4. Frontier molecular orbital of acetanilide.

Table 7. Comparison of HOMO, LUMO and energy gaps of acetanilide. 
Table 8. Comparison of molecular properties of acetanilide.

\begin{tabular}{lcccc}
\hline \multirow{2}{*}{ Molecular properties } & \multicolumn{2}{c}{$6-31 \mathrm{G}(\mathrm{d})$} & \multicolumn{2}{c}{$6-31+\mathrm{G}(\mathrm{d}, \mathrm{p})$} \\
\cline { 2 - 5 } & $\mathrm{HF}$ & B3LYP & HF & B3LYP \\
\hline Chemical hardness $(\eta)$ & 6.0834 & 2.8366 & 5.0321 & 2.7861 \\
Softness $(\mathrm{S})$ & 0.1644 & 0.3525 & 0.1987 & 0.3589 \\
Chemical potential $(\mu)$ & -2.1724 & -3.1166 & -3.4318 & -3.5227 \\
Electronegativity $(\chi)$ & 2.1724 & 3.1166 & 3.4318 & 3.5227 \\
Electrophilicity index $(\chi)$ & 0.3879 & 1.7121 & 1.1702 & 2.2270 \\
\hline
\end{tabular}

\section{Conclusion}

In the present work, the molecular structural parameters like bond length, bond angle, dihedral angle and vibrational frequencies of the fundamental modes of optimized geometry have been determined from HF and DFT calculations using different level of basis sets. The computed geometrical parameters are compared with the observed X-ray diffraction data of similar compounds. The close agreement between the experimental and scaled frequencies was observed. The HOMO-LUMO energy gap has been calculated to get the global reactivity descriptors of the titled molecule. The calculated molecular properties may lead to the understanding of stability and activity of acetanilide and the results will be of assistance in the quest of the experimental and theoretical evidence for the acetanilide in reaction intermediates and pharmaceuticals.

\section{References}

Baena, Y., Pinzon, J.A., Barbosa, H.J. and Martinez, F. 2004. Temperature-dependence of the solubility of some acetanilide derivatives in several organic and aqueous solvents. Phys. Chem. Liq. 42, 603.

Bertolini, A., Ferrari, A., Ottani, A., Guerzoni, S., Tacchi, R. and Leone, S. 2006. Paracetamol: new vistas of an old drug. CNS Drug Rev. 12, 250.

Brown, C. J. and Corbridge, D. E. C. 1954. The crystal structure of acetanilide. Acta Cryst. 7, 711.

Chattaraj, P. K., Maiti, B. and Sarkar, U. 2003. Philicity: a unified treatment of chemical reactivity and selectivity. $J$. Phys. Chem. A. 107, 4973-4975.

Cheshmedzhieva, D., Ilieva, S. and Galabov, B. 2004. Computational study of the alkaline hydrolysis of acetanilide. J. Mole. Struct. (Theochem). 681, 105-112.
Cheshmedzhieva, D. Ilieva, S. and Galabov, B. 2004. Computational study of the alkaline hydrolysis of acetanilide. J. Mole. Struct. (Theochem). 681, 105-112.

Decoret, C. and Tinland, B. 1971. A theoretical study of the electronic structure and spectrum of acetanilide. Spectroscopy Lett. 4, 263-266.

Decoret, C. and Tinland, B. 1972. A theoretical PCILO study of the conformation of acetanilide. J. Mole. Struct. (Theochem). 12, 485-487.

Dennington, II R.D., Keith, T. A. and Millam, J. M. 2009. GaussView 5.0. Wallingford, CT.

Frisch, M.J., Trucks, G.W., Schlegel, H.B., Scuseria, G.E., Robb, M.A., Cheeseman, J.R., Scalmani, G., Barone, V., Mennucci, B.G., Petersson, A., Nakatsuji, H., Caricato, M., Li, X., Hratchian, H.P., Izmaylov, A.F., Bloino, J., Zheng, G., Sonnenberg, J.L., Hada, M., Ehara, Toyota, M.K., Fukuda, R., Hasegawa, J., Ishida, M., Nakajima, T., Honda, Y., Kitao, O., Nakai, H., Vreven, T., Montgomery Jr., J.A., Peralta, J.E., Ogliaro, F., Bearpark, M., Heyd, J.J., Brothers, E., Kudin, K.N., Staroverov, V.N., Kobayashi, R., Normand, J., Raghavachari, Rendell, K.A., Burant, J.C., Iyengar, S.S., Tomasi, J., Cossi, M., Rega, N., Millam, J.M., Klene, M., Knox, J.E., Cross, J.B., Bakken, V., Adamo, C., Jaramillo, J., Gomperts, R., Stratmann, R.E., Yazyev, O., Austin, A.J., Cammi, R., Pomelli, C., Ochterski, J.W., Martin, R.L., Morokuma, K., Zakrzewski, V.G., Voth, G.A., Salvador, P., Dannenberg, J.J., Dapprich, S., Daniels, A.D., Farkas, O., Foresman, J.B., Ortiz, J.V., Cioslowski, J. and Fox, D.J. 2009. Gaussian 09, Revision A.02, Gaussian, Inc., Wallingford, CT.

Gerhartz, W. (exec ed.). 1985. Ullmann's encyclopedia of industrial chemistry. 5th ed. Deerfield Beach, FL: VCH Publishers, A1, VA2310.

Gnanasambandan, T., Gunasekaran, S. and Seshadri, S. 2014. Experimental and theoretical study of p-nitroacetanilide. Spectrochim. Acta A Mol. Biomol. Spectros. 117, 557567. 
Govindarajan, M., Karabacak, M., Periandy, S. and Xavier, S. 2012. Vibrational spectroscopic studies, NLO, HOMOLUMO and electronic structure calculations of $\alpha, \alpha, \alpha-$ trichlorotoluene using HF and DFT. Spectrochim. Acta A Mol. Biomol. Spectros. 94, 53-64.

Hamm, P. and Tsironis, G. P. 2007. Semiclassical and quantum polarons in acetanilide. Eur. Phys. J. Spec. 147, 303-331.

Internet 1. http://www.hanhonggroup.com/ir/ir_en/B17217. html. Retrieved April 13, 2016.

Itoh, K. and Shimanouchi T. 1969. Far-infrared spectra of acetanilide. Spectro. Chimics. Acta. 25A, 290-293.

Lewis, R. J., Sr (Ed.). 1993. Hawley's condensed chemical dictionary. 12th ed. New York, NY: Van Nostrand Rheinhold Co., 6.

Merrick, J. P., Moran, D. and Radom, L. 2007. An evaluation of harmonic vibrational frequency scale factors. J. Phys. Chem. A. 111, 11683-11700.

Morrison, R. T. and Boyd, R. N. 2005. Organic chemistry, $6^{\text {th }}$ edition, Prentice Hall, Inc. 767.

Munoz-Caro, C., Niño, A., Senent, M. L., Leal, J. M. and Ibeas, S. 2000. Modeling of protonation processes in acetohydroxamic acid. J. Org. Chem. 65, 405-410.

Parr, R. G. and Pearson, R. G. 1983. Absolute hardness: companion parameter to absolute electronegativity. $J$. Am. Chem. Soc. 105, 7512-7516.

Parr, R. G., Szentpály, L. V., Liu, S. 1999. Electrophilicity index. J. Am. Chem. Soc. 121, 1922-1924.

Parr, R. G. and Chattraj, P. K. 1991. Principle of maximum hardness. J. Am. Chem. Soc. 113, 1854-1855.
Parr, R. G., Donnelly R. A., Levy, M. and Palke, W. E. 1978. Electronegativity: the density functional viewpoint. $J$. Chem. Phys. 68, 3801-3807.

Parthasarathi, R., Padmanabhan, J., Elango, M., Subramanian, V. and Chattaraj, P. 2004a. Intermolecular reactivity through the generalized philicity concept. Chem. Phys. Lett. 394, 225-2230.

Parthasarathi, R., Padmanabhan, J., Subramanian, V., Maiti, B. and Chattaraj, P. 2004b. Toxicity analysis of 33'44'5pentachloro biphenyl through chemical reactivity and selectivity profiles. Curr. Sci. 86, 535-542.

Parthasarathi, R., Padmanabhan, J., Subramanian, V., Sarkar, U., Maiti, B. and Chattaraj, P. 2003. Toxicity analysis of benzidine through chemical reactivity and selectivity profiles: A DFT approach. Int. Electron. J. Mol. Des. 2, 798-813.

Pereira, J. L., Hill, C. J., Sibly, R. M., Bolshakov, V. N., Goncalves, F., Heckmann, L. H. and Callaghan, A. 2010. Gene transcription in Daphnia magna: effects of acute exposure to a carbamate insecticide and an acetanilide herbicide. Aquat. Toxicol. 97, 268-276.

Santamaria, R., Cocho, G., Corona, L. and González, E. 1998. Molecular electrostatic potentials and Mulliken charge populations of DNA mini-sequences. J. Chem. Phys. 227, 317-329.

Wasserman, H. J., Ryan, R. R. and Layne, S. P. 1985. Structure of acetanilide $\left(\mathrm{C}_{8} \mathrm{H}_{9} \mathrm{NO}\right)$ at $113 \mathrm{~K}$. Acta Cryst. C41, 783-785.

Weast R. C., (Ed.). 1981. CRC handbook of chemistry and physics, 62nd ed., CRC Press, Boca Raton, FL, C-67. 